\title{
Differing Erythrocyte Membrane Skeletal Protein Defects in Alpha and Beta Thalassemia
}

\author{
E. Shinar, ${ }^{\ddagger}$ E. A. Rachmilewitz, ${ }^{\star}$ and S. E. Lux* \\ *Division of Hematology-Oncology, The Children's Hospital and Dana Farber Cancer Institute, Harvard Medical School, Boston, \\ Massachusetts 02115; and ${ }^{\ddagger}$ Department of Hematology, Hadassah Medical Center, Jerusalem, Israel
}

\begin{abstract}
Thalassemic red cells show irregular morphology and maldistribution of glycoproteins and sialic acids. These changes are compatible with damage to the red cell membrane skeleton. To test this possibility, we systematically studied the interconnections of skeletal proteins in patients with a form of alpha thalassemia ( $\mathrm{HbH}$ disease), in patients with beta thalassemia intermedia, and in normal individuals. Alpha- and beta-thalassemic spectrin functions normally in spectrin self-association, binding to normal inside-out vesicles (IOVs), and binding to actin in the presence and absence of normal protein 4.1. Binding of normal spectrin to beta:thalassemic IOVs is normal but alpha-thalassemic IOVs are defective and bind only half the normal amount of spectrin (66 \pm 5 vs. $120 \pm 16 \mu \mathrm{g}$ spectrin dimer/mg IOV protein, respectively). A different defect is detected in beta thalassemia, in which protein 4.1 shows markedly reduced ability ( $48 \pm 7 \%$ of normal) to enhance the binding of normal spectrin to actin and a decreased ability to bind normal spectrin in a binary interaction, compared with normal protein $4.1(24 \pm 1$ and $43 \pm 1 \mu$ grotein $4.1 / \mathrm{mg}$ spectrin, respectively). As no quantitative deficiency of beta-thalassemic protein 4.1 is detected, we assume an acquired lesion is present, which affects about half of the protein 4.1 molecules. These findings indicate that specific, localized, yet different defects exist in the skeletal proteins of alpha- and beta-thalassemic red cells. The different molecular lesions imply that the mechanism of hemolysis and probably the interaction of unpaired globin chains with the membrane differs in the two diseases.
\end{abstract}

\section{Introduction}

Studies of the thalassemic syndromes have concentrated intensively on the primary genetic defects in hemoglobin synthesis (1). The mechanisms leading to the premature destruction of the abnormal red blood cells (RBCs) in the bone marrow sinusoids and the peripheral circulation have not been clearly defined. It is generally assumed that the extra, unmatched globin chains precipitate in the erythrocyte, resulting in widespread membrane dysfunction (see reference 2 for review). Indeed, alterations in the phospholipid and cholesterol content, increased intracellular calcium concentration, and changes in

Address reprint requests to Dr. Samuel E. Lux IV, The Children's Hospital, 300 Longwood Avenue, Boston, MA 02115.

Received for publication 31 March 1987 and in revised form 3 March 1988.

J. Clin. Invest.

(c) The American Society for Clinical Investigation, Inc.

0021-9738/89/02/0404/07 \$2.00

Volume 83, February 1989, 404-410 the membrane sialic acid residues have been documented in beta thalassemia (2). Thalassemic red cells are more sensitive to oxidant stress, as reflected by an increase in malonyldialdehyde formation, a decrease in polyunsaturated fatty acids (3), an increase in protein cross-linking (4), and a decrease in titratable membrane thiols (5). This oxidant susceptibility may be due to excessive oxidation of the unstable globin chains and the subsequent release of oxygen radicals that theoretically might damage any component of the red cell membrane.

The abnormal morphology and irregular shape of thalassemic red cells suggest that the erythrocyte membrane skeleton must be damaged. The skeletal protein network is thought to be important in regulating different functions, including the deformability and stability of red cell membranes (6). Analyses of the latter parameters in thalassemic cells show that whereas both alpha- $(\mathrm{HbH})^{1}$ and beta-thalassemic membranes are unusually rigid, beta-thalassemic membranes are also fragile and fragment twice as rapidly as normal at high shear stress (7). We have also recently examined the membrane protein skeletons of beta-thalassemic red cells by scanning electron microscopy and found abnormalities in their shape and protein composition (8).

The goal of this study was to characterize the defects in the membrane skeletons of alpha- and beta-thalassemic red cells, and to analyze the similarities and differences between the two syndromes. We therefore studied systematically the major skeletal proteins interactions in patients with alpha and beta thalassemia. We found a qualitative defect in the binding of normal spectrin to inside-out vesicles (IOVs) in alpha thalassemia, and a different defect in the interaction of spectrin, actin, and protein 4.1 in beta thalassemia. The latter is caused by the presence of abnormal protein 4.1 molecules, with reduced ability to bind normal spectrin. These findings indicate that specific, localized skeletal protein damage occurs in thalassemia, and the damage differs in alpha and beta thalassemia.

\section{Methods}

Subjects. Venous blood samples in citrate-phosphate-dextrose were collected from splenectomized and nonsplenectomized normal individuals $(n=20)$ and from patients with alpha thalassemia (HbH disease; $n=3$ ) and beta thalassemia intermedia $(n=11)$. Informed

1. Abbreviations used in this paper: Buffer A, $130 \mathrm{mM} \mathrm{KCl}, 20 \mathrm{mM}$ $\mathrm{NaCl}, 10 \mathrm{mM}$ sodium phosphate, $1 \mathrm{mM}$ EDTA, $1 \mathrm{mM}$ DTT, $1 \mathrm{mM}$ $\mathrm{MgCl}_{2}$, and $0.5 \mathrm{mM}$ sodium azide, $\mathrm{pH} 7.5$; buffer $\mathrm{B}, 150 \mathrm{mM} \mathrm{NaCl}, 4$ $\mathrm{mM}$ sodium phosphate, $10 \mathrm{mM}$ Tris, $0.5 \mathrm{mM}$ DTT, $0.1 \mathrm{mM} \mathrm{ATP}$, $0.01 \mathrm{mM} \mathrm{CaCl}, 4 \mathrm{mg} / \mathrm{ml} \mathrm{BSA}, \mathrm{pH} 7.4$; buffer $\mathrm{C}, 10 \mathrm{mM}$ sodium phosphate, $130 \mathrm{mM} \mathrm{KCl}, 20 \mathrm{mM} \mathrm{NaCl}, 1 \mathrm{mM}$ EDTA, $0.5 \mathrm{mM}$ sodium azide (pH 7.6), $1 \mathrm{mg} / \mathrm{ml} \mathrm{BSA}$, and $0.1 \%$ NP-40; buffer D, 130 $\mathrm{mM} \mathrm{KCl}, 20 \mathrm{mM} \mathrm{NaCl}, 10 \mathrm{mM}$ Tris $\mathrm{Cl}, 1 \mathrm{mM}$ EDTA, $1 \mathrm{mM} \mathrm{NaN}_{3}$, and $0.1 \mathrm{mM}$ DTT, pH 7.6; $\mathrm{HbH}$, hemoglobin $\mathrm{H}$ disease; $\mathrm{IOV}$, insideout vesicle; RBC, red blood cell. 
consent was obtained from all participants. The thalassemic samples were obtained from patients who rarely require blood transfusions. None of the patients had been transfused in the 4 mo preceding the study. The detailed hemoglobin analysis and globin chain synthesis ratios of many of the patients have been previously described (9). Some samples were obtained from Israeli patients, and were shipped on ice by air express, accompanied by a normal control. All blood samples were received and studied within 24-36 h after blood collection. No differences were observed between samples shipped from Jerusalem and samples obtained locally.

Preparation of red cell membranes and membrane proteins. RBC membranes were prepared by hypotonic lysis in $5 \mathrm{mM}$ sodium phosphate, pH 8 (10) with the addition of $1 \mathrm{mM}$ EDTA and protease inhibitors ( $2 \mathrm{mM}$ diisopropyl fluourophosphate, $5 \mu \mathrm{g} / \mathrm{ml}$ leupeptin) to the lysis buffer. Ratios of various membrane proteins were determined by running RBC membranes on a $3.5-17 \%$ exponential SDS-polyacrylamide gel (11). In most experiments, the Coomassie Blue-stained bands of spectrin, ankyrin, protein 3, protein 4.1, and globin were cut from four to six lanes, the dye was eluted with $25 \%$ pyridine, and the relative protein content was estimated by absorbance at $605 \mathrm{~nm}$ (12). In some experiments, the ratios were determined by densitometry of Coomassie Blue-stained gels.

Spectrin-depleted IOVs were separated from low ionic strength extracts by sedimentation and layered on a Dextran barrier (13). The sidedness of the IOVs was determined by measuring the glyceraldehyde-3-phosphate dehydrogenase activity before and after the addition of $0.2 \%$ Triton X-100, as described by Steck and Kant (14). Spectrin was isolated by low ionic strength extraction with $0.1 \mathrm{mM}$ sodium phosphate, $\mathrm{pH} 8$, at $37^{\circ} \mathrm{C}$, and purified by gel filtration chromatography on Agarose A15M 200-400 mesh (Bio-Rad Laboratories, Richmond, CA) as described (15).

Protein 4.1 was purified from fresh red cell membranes by high salt extraction with $1 \mathrm{M} \mathrm{KCl}$, as described by Tyler (16) and modified by Cohen and Foley (17). Actin was prepared from rabbit skeletal muscle by the method of Spudich and Watt (18). It has been previously shown that this actin is equivalent to erythrocyte actin in assays of spectrinactin-protein 4.1 interactions (19).

The spectrin and protein 4.1 were iodinated with ${ }^{125} \mathrm{I}$-Bolton Hunter reagent (New England Nuclear, Boston, MA) (20). Analysis of protein concentration was performed by the method of Lowry (21) using a BSA standard.

Membrane skeletal protein interactions. Spectrin self-association was analyzed by nondenaturing gel electrophoresis at $0^{\circ} \mathrm{C}$, as described (22). The proportions of spectrin dimer, tetramers, and oligomers in low temperature $\left(4^{\circ} \mathrm{C}\right)$, low ionic strength extracts were studied directly. The interconversion of spectrin tetramers to dimer was also determined during incubation of these extracts for $6 \mathrm{~h}$ at $30^{\circ} \mathrm{C}(22)$. Interactions of spectrin and ankyrin on IOVs were studied by rebinding ${ }^{125} \mathrm{I}$-spectrin dimer to spectrin depleted IOVs in $130 \mathrm{mM} \mathrm{KCl}, 20$ $\mathrm{mM} \mathrm{NaCl}, 10 \mathrm{mM}$ sodium phosphate, $1 \mathrm{mM}$ EDTA, $1 \mathrm{mM}$ DTT, 1 $\mathrm{mM} \mathrm{MgCl}$, and $0.5 \mathrm{mM}$ sodium azide, $\mathrm{pH} 7.5$ (buffer A) for $90 \mathrm{~min}$ at $0^{\circ} \mathrm{C}$. Free and membrane-bound radioactivity was determined by pelleting the IOVs through $20 \%$ sucrose in the binding buffer (wt/vol), as described by Goodman and Weidner (23). Samples of ${ }^{125} \mathrm{I}$-spectrin were heat denatured $\left(60^{\circ} \mathrm{C}, 10 \mathrm{~min}\right)$ and tested at various spectrin concentrations in each experiment to estimate the amount of nonspecific binding. Such binding was $<15 \%$ of the values of untreated spectrin and was routinely subtracted.

Interaction of thalassemic spectrin with $\mathrm{F}$ actin and protein 4.1 was studied in an assay designed by Wolfe et al. (24), as modified by Becker et al. (25), where increasing concentrations of ${ }^{125} \mathrm{I}$-spectrin dimer (10-30 $\mu \mathrm{g})$ were incubated with $24 \mu \mathrm{g} \mathrm{F}$ actin in the presence or absence of protein $4.1(0$ or $6 \mu \mathrm{g})$ in $150 \mathrm{mM} \mathrm{NaCl}, 4 \mathrm{mM}$ sodium phosphate, $10 \mathrm{mM}$ Tris, $0.5 \mathrm{mM}$ DTT, $0.1 \mathrm{mM} \mathrm{ATP,} 0.01 \mathrm{mM} \mathrm{CaCl}_{2}$, $4 \mathrm{mg} / \mathrm{ml} \mathrm{BSA}$, pH 7.4 (buffer B) for $60 \mathrm{~min}$ at $23^{\circ} \mathrm{C}$. In a few experiments, designed to test the function of protein 4.1 , increasing concentrations of $4.1(0-3 \mu \mathrm{g})$ were incubated with fixed amounts of ${ }^{125} \mathrm{I}$-normal spectrin dimer $(12 \mu \mathrm{g})$ and $\mathrm{F}$ actin $(21 \mu \mathrm{g})$ for $1 \mathrm{~h}$ at $24^{\circ} \mathrm{C}$ in 130
$\mathrm{mM} \mathrm{KCl}, 20 \mathrm{mM} \mathrm{NaCl}, 10 \mathrm{mM}$ Tris $\mathrm{Cl}, 1 \mathrm{mM}$ EDTA, $1 \mathrm{mM} \mathrm{NaN} 3$, and $0.1 \mathrm{mM}$ DTT, $\mathrm{pH} 7.6$ (buffer $\mathrm{D}$ ). In both cases the F actin was then collected by centrifugation $(48,000 \mathrm{~g}$ for $120 \mathrm{~min})$ through a $10 \%$ (wt/vol) sucrose cushion in the binding buffer, and the pellet was counted to determine the amount of bound ${ }^{125} \mathrm{I}$-spectrin. Control samples containing ${ }^{125} \mathrm{I}$-spectrin alone were included in each assay and the nonspecific counts, which did not exceed 5\%, were subtracted from the binding data. The assay was also performed in the presence and absence of DTT to test whether thalassemic skeletal proteins had incurred reversible oxidative damage.

In another set of experiments, a fixed amount of normal ${ }^{125}$ I-spectrin $(10 \mu \mathrm{g})$ was incubated with $21 \mu \mathrm{g} \mathrm{F}$ actin, in the presence of increasing concentrations of thalassemic or normal protein $4.1(0-3$ $\mu \mathrm{g})$, under the same experimental conditions.

Interaction of spectrin and purified protein 4.1 was studied by binding ${ }^{125}$ I-protein 4.1 to spectrin-Sepharose (Pharmacia Fine Chemicals, Piscataway, $\mathrm{NJ}$ ) in a modification of the method described by Becker et al. (26). Briefly, normal spectrin dimer $(1-2 \mathrm{mg} / \mathrm{ml})$ was attached to $\mathrm{CNBr}$-Sepharose $4 \mathrm{~B}$ ( $5 \mathrm{mg}$ spectrin/g dry beads) in $0.1 \mathrm{M}$ sodium bicarbonate and $0.15 \mathrm{M} \mathrm{NaCl}, \mathrm{pH} 8$ at $4^{\circ} \mathrm{C}$ for $16 \mathrm{~h}$ mixing end over end. The coupling efficiency was generally $>90 \%$. Control beads were prepared by coupling Sepharose to BSA at the same concentration. These were used to assess nonspecific binding. A fixed amount of spectrin-Sepharose (40 $\mu \mathrm{g}$ spectrin) or an equivalent amount of BSA-Sepharose was incubated with ${ }^{125}$ I-protein 4.1 (0-18 $\mu \mathrm{g})$ in $10 \mathrm{mM}$ sodium phosphate, $130 \mathrm{mM} \mathrm{KCl}, 20 \mathrm{mM} \mathrm{NaCl}, 1 \mathrm{mM}$ EDTA, $0.5 \mathrm{mM}$ sodium azide, $(\mathrm{pH} 7.6), 1 \mathrm{mg} / \mathrm{ml} \mathrm{BSA}$, and $0.1 \%$ NP-40 (Calbiochem-Behring Corp., La Jolla, CA) (buffer C) for $90 \mathrm{~min}$ at $0^{\circ} \mathrm{C}$. The spectrin-Sepharose or albumin-Sepharose and protein 4.1 mixtures were layered over $20 \%$ sucrose in the same buffer, centrifuged at $5,000 \mathrm{rpm}$ for $15 \mathrm{~min}$, and the pellets were assayed for radioactivity. The nonspecific binding on the BSA-Sepharose was $<10 \%$ of the binding values to the spectrin-Sepharose and was subtracted. The purified spectrin and protein 4.1 were clarified by centrifugation at 100,000 $g$ for $\mathbf{4 5}$ min before binding in these experiments.

$P A G E$. PAGE in the presence of SDS was performed using the continuous method of Fairbanks (10) as modified by Steck (27), and the discontinuous method of Laemmli (28). PAGE in the absence of detergents was performed on $3 \%$ acrylamide tube gels.

\section{Results}

Composition of ghosts and vesicles. SDS-PAGE of red cell membranes and spectrin-depleted IOVs from thalassemic patients and normal individuals are shown in Fig. $1 A$ and $B$ and quantified in. Table I. There is a mild to moderate decrease in the spectrin content of both alpha-thalassemic (13\% decrease) and beta-thalassemic ( $23 \%$ decrease) membranes. Similar spectrin deficiency has been observed previously in beta thalassemia by Shinar et al. (18). There is also an increase in the hemoglobin content of the alpha- and beta-thalassemic membranes, reaching $10 \pm 2$ and $13 \pm 4 \%$, respectively, of the total membrane protein, as calculated by densitometry or pyridine elution. An increase of cytoplasmic proteins, like catalase, is also detected, which has been described for other hemolytic anemias (29). The protein composition of spectrin-depleted thalassemic and normal IOVs is comparable (Fig. $1 B$, Table I), except for the presence of hemoglobin, which is normally undetectable, but reaches $0.5-5 \%$ of the total thalassemic membrane protein content. No quantitative deficiency of ankyrin or protein 4.1 is detected when thalassemic ghosts and IOVs are studied using pyridine elution of Coomassie Bluestained gel bands (Table I). There is no difference in sidedness between thalassemic and normal IOVs.

Protein 4.1 purified from thalassemic membranes has the same mobility on SDS-PAGE as normal 4.1 (Fig. 1C), but has 


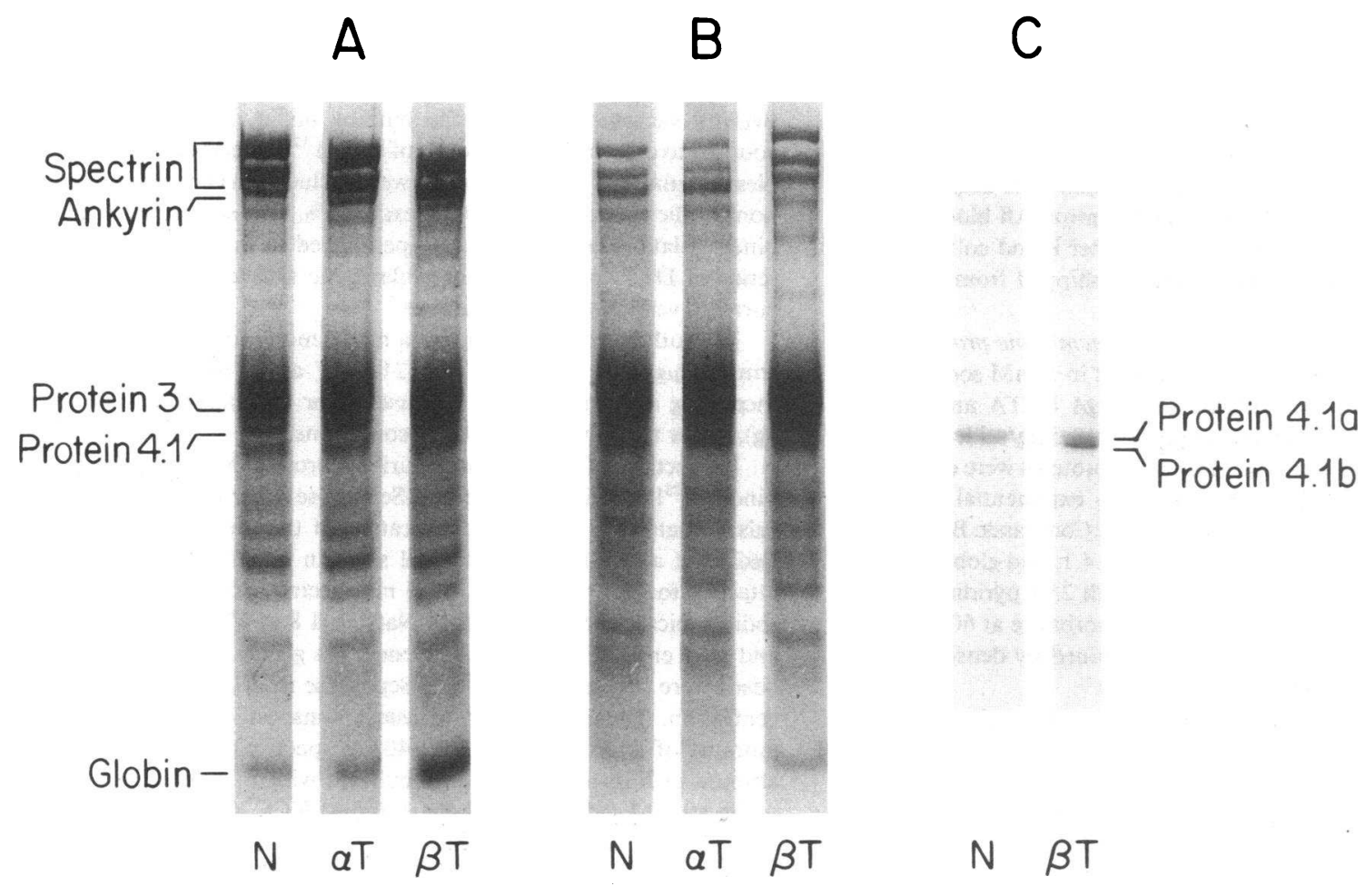

Figure 1. Gel electrophoresis of red cell membranes and isolated protein 4.1 from thalassemic patients and normal individuals. $(A)$ Normal, alpha-thalassemic, and beta-thalassemic red cell membranes. $(B)$ Normal, alpha-thalassemic, and beta-thalassemic spectrin-depleted IOVs. Electrophoresis was performed using a continuous system (11) and $30 \mu \mathrm{g}$ of membranes and IOVs were applied to the gel. Both types of thalassemic membranes contain increased amounts of globin and other cytoplasmic proteins. $(C)$ Normal and beta thalassemic protein 4.1. Electrophoresis was performed using a discontinuous system (28). There is an increased amount of the $4.1 \mathrm{~b}$ subfraction in the thalassemic protein 4.1 , presumably due to the young age of the thalassemic red cells (30).

a more prominent $4.1 \mathrm{~b}$ component, presumably due to the young age of the thalassemic erythrocytes (30).

Low ionic strength spectrin extracts (at 4 and $37^{\circ} \mathrm{C}$ ) from thalassemic patients are normal in SDS-PAGE mobility, gel filtration elution pattern, and yield (data not shown).

Spectrin self-association. Thalassemic spectrin-spectrin interactions are normal. Both alpha- and beta-thalassemic spec-

Table I. Quantitation of Membrane Proteins in Normal and Thalassemic Ghosts and IOVs

\begin{tabular}{lccc}
\hline \multicolumn{1}{c}{ Ratio } & Normal & Alpha thalassemia & Beta thalassemia \\
\hline Membranes & & & \\
Spectrin/protein 3 & 1.51 & 1.32 & 1.16 \\
Ankyrin/protein 3 & 0.39 & 0.39 & 0.44 \\
4.1/protein 3 & 0.37 & 0.46 & 0.42 \\
Globin/protein 3 & 0.24 & 0.35 & 0.49 \\
IOVs & & & \\
Spectrin/protein 3 & 0.31 & 0.25 & 0.42 \\
Ankyrin/protein 3 & 0.24 & 0.27 & 0.22 \\
4.1/protein 3 & 0.38 & 0.36 & 0.36 \\
Globin/protein 3 & ND* & 0.05 & 0.10 \\
\hline
\end{tabular}

Ratios of dye eluted from Coomassie blue-stained gel bands by $25 \%$ pyridine (12). Average of experiments on two unrelated individuals; each in triplicate.

* ND, none detected. trin extracts show normal ratios of spectrin dimer/spectrin tetramer in both low $\left(4^{\circ} \mathrm{C}\right)$ and high $\left(37^{\circ} \mathrm{C}\right)$ temperature extracts.

There is a small increase in the percentage of spectrin oligomers in the thalassemic extracts (thalassemic 38\%; normal $29 \%$ ) as evaluated by densitometry of low temperature extracts on $3 \%$ nondenaturing gels (Fig. $2 \mathrm{~A}$; Table II). We also detect a small amount ( $\sim 4 \%$ of the total spectrin) of a fast mobility band migrating approximately in the position of spectrin monomer (26) in splenectomized patients with alpha $(n=1)$ and beta thalassemia $(n=4)$ (Fig. $2 B$, Table II). This was not observed in nonsplenectomized thalassemic patients or in either splenectomized or nonsplenectomized individuals. This band may represent oxidized spectrin (26) or a complex between spectrin and globin (31).

In solution, equivalent proportions of alpha thalassemic, beta thalassemic, and normal spectrin tetramer convert to dimer (alpha thalassemic 92\%; beta thalassemic 94\%; normal 93\%) during 6-h incubations at $30^{\circ} \mathrm{C}$ (data not shown).

Spectrin ankyrin interactions. The ankyrin binding sites of thalassemic spectrins are normal as assessed by rebinding alpha- or beta-thalassemic ${ }^{125} \mathrm{I}$-spectrin dimer $(0-80 \mu \mathrm{g} / \mathrm{ml})$ to normal spectrin-depleted IOVs (Fig. $3 \mathrm{~A}$ ).

The binding of normal ${ }^{125} \mathrm{I}$-spectrin to beta-thalassemic IOVs is also normal (Fig. $3 \mathrm{~B}$ ) and comparable to that reported by Bennett and Branton (13); however, alpha-thalassemic IOVs bind less spectrin than normal IOVs (Fig. 3 B). Scatchard analyses (Fig. $3 \mathrm{~B}$, inset) indicate that the binding capacity of 


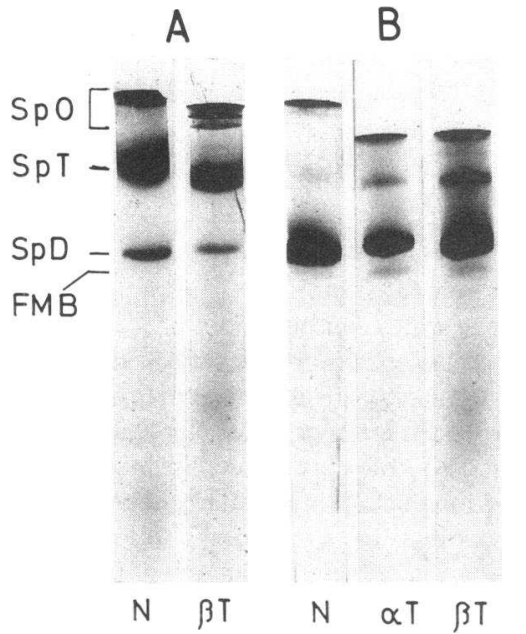

$N \quad N \quad N \quad \alpha T$
Figure 2. Nondenaturing gel electrophoresis of normal $(\mathrm{N})$ and thalassemic $(\alpha \mathrm{T}, \beta \mathrm{T})$ spectrin extracts. Samples were obtained by incubating red cell membranes at either $(A) 4^{\circ} \mathrm{C}$ for $16 \mathrm{~h}$ or $(B)$ at $37^{\circ} \mathrm{C}$ for $30 \mathrm{~min}$ in low ionic strength buffer. Note the increased amount of spectrin oligomer $(\mathrm{SpO})$ in the beta-thalassemic but not the normal spectrin extracts prepared at $4^{\circ} \mathrm{C}$. Also note the presence of a fast migrating band (FMB) in the $37^{\circ} \mathrm{C}$ spectrin extracts. SpT represents spectrin tetramer; $\mathrm{SpD}$, spectrin dimer.

alpha-thalassemic IOVs is $66 \pm 5 \mu \mathrm{g}$ spectrin dimer/mg IOV protein, whereas normal IOVs bind approximately twice as much spectrin: $120 \pm 16 \mu \mathrm{g}$ spectrin dimer/mg IOV protein. The binding affinities are similar: the $K_{\mathrm{d}}$ for normal and alpha-thalassemic IOVs are 45 and $53 \mu \mathrm{g} / \mathrm{ml}$, respectively.

Spectrin-actin-protein 4.1 interactions. The interaction of thalassemic spectrins with $F$ actin and protein 4.1 is normal. Alpha- and beta-thalassemic spectrin dimers show normal binding to $\mathrm{F}$ actin in the presence or absence of normal protein 4.1 (Fig. $4 \mathrm{~A}$ ). This normal binding ability is maintained when the assay is done in the absence of DTT (data not shown). This rules out the possibility that thalassemic spectrins undergo reversible oxidative damage that might have been corrected under the usual experimental conditions.

In contrast, the ability of beta-thalassemic protein 4.1 to enhance spectrin-actin interaction is abnormal. As shown in Fig. $4 \mathrm{~B}$, beta-thalassemic protein 4.1 has markedly impaired ability to enhance the binding of normal spectrin dimer to actin ( $48 \pm 7 \%$ of normal), when compared with normal protein 4.1. The ability of alpha thalassemic protein 4.1 to interact with normal spectrin and actin is comparable to normal.

The binding of beta-thalassemic 4.1 to spectrin is also ab-

Table II. Percent of Spectrin Oligomers, Tetramers, Dimers and Fast Migrating Band in 4 and $37^{\circ} \mathrm{C}$ Spectrin Extracts of Alpha- and Beta-Thalassemic Membranes

\begin{tabular}{lccccccc}
\hline & \multicolumn{3}{c}{$4^{\circ} \mathrm{C}$} & & 3 & $37^{\circ} \mathrm{C}$ & \\
\cline { 2 - 6 } \cline { 6 - 8 } & $\mathrm{SpO}^{*}$ & $\mathrm{SpT}$ & $\mathrm{SpD}$ & $\mathrm{SpT}$ & $\mathrm{SpD}$ & $\mathrm{FMB}$ \\
\hline Normal & $29 \pm 1$ & $55 \pm 1$ & $16 \pm 1$ & $6 \pm 3$ & $94 \pm 4$ & $\mathrm{ND}^{\ddagger}$ \\
Alpha thalassemia & $38 \pm 2$ & $49 \pm 1$ & $15 \pm 1$ & $10 \pm 2$ & $86 \pm 2$ & $5 \pm 1$ \\
Beta thalassemia & $38 \pm 3$ & $50 \pm 1$ & $12 \pm 2$ & $12 \pm 2$ & $84 \pm 3$ & $4 \pm 2$
\end{tabular}

* SpO, Spectrin oligomers; $\mathrm{SpT}$, spectrin tetramers; $\mathrm{SpD}$, spectrin dimers; FMB, fast migrating band.

$¥ \mathrm{ND}$, none detected.
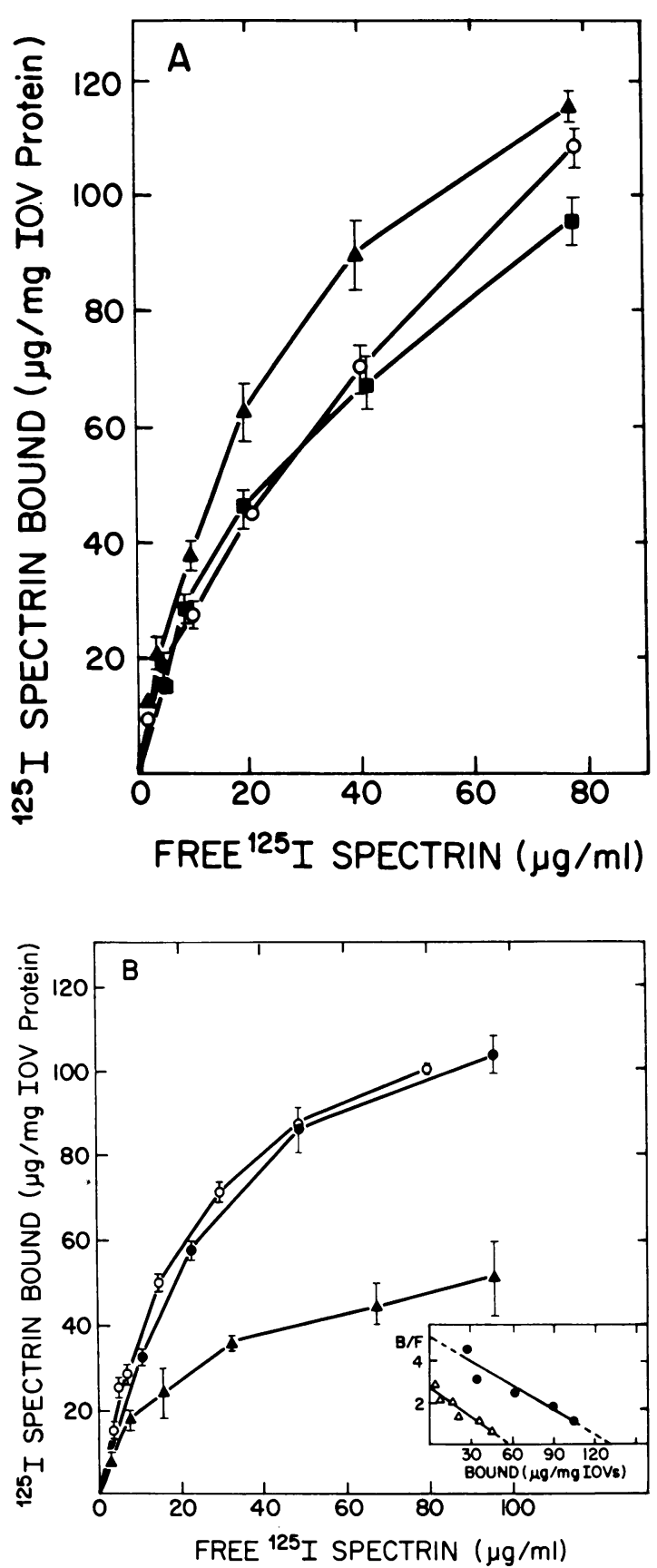

Figure 3. (A) Binding of normal (O), alpha-thalassemic ( $\Delta$ ), and betathalassemic ( $\boldsymbol{\omega})$ spectrin dimer to normal spectrin-depleted IOVs in two different experiments. Various concentrations of ${ }^{125} \mathrm{I}$-spectrin dimer $(0-100 \mu \mathrm{g} / \mathrm{ml})$ were incubated with $16.7 \mu \mathrm{g} \mathrm{IOVs}$ for $90 \mathrm{~min}$ at $0^{\circ} \mathrm{C}$ in buffer $\mathrm{A}$ (see Methods). Error bars depict the SD. Note that thalassemic spectrin functions normally in this assay. $(B)$ Binding of normal spectrin dimer to normal (O), alpha-thalassemic ( $\mathbf{\Delta})$, and beta-thalassemic ( $\square$ ) spectrin-depleted IOVs. The results of 10 experiments are shown. The data plotted according to the Scatchard equation (inset) show that the maximal capacity of normal and alpha-thalassemic IOVs was $120 \pm 14$ and $66 \pm 5 \mu \mathrm{g}$ spectrin dimer/mg IOVs protein, respectively.

normal. When this binary interaction is studied by binding protein 4.1 to normal spectrin attached to Sepharose beads, a reduction of $45 \pm 2 \%$ is detected in the ability of beta-thalassemic protein 4.1 to bind normal spectrin (Fig. 5). Scatchard 

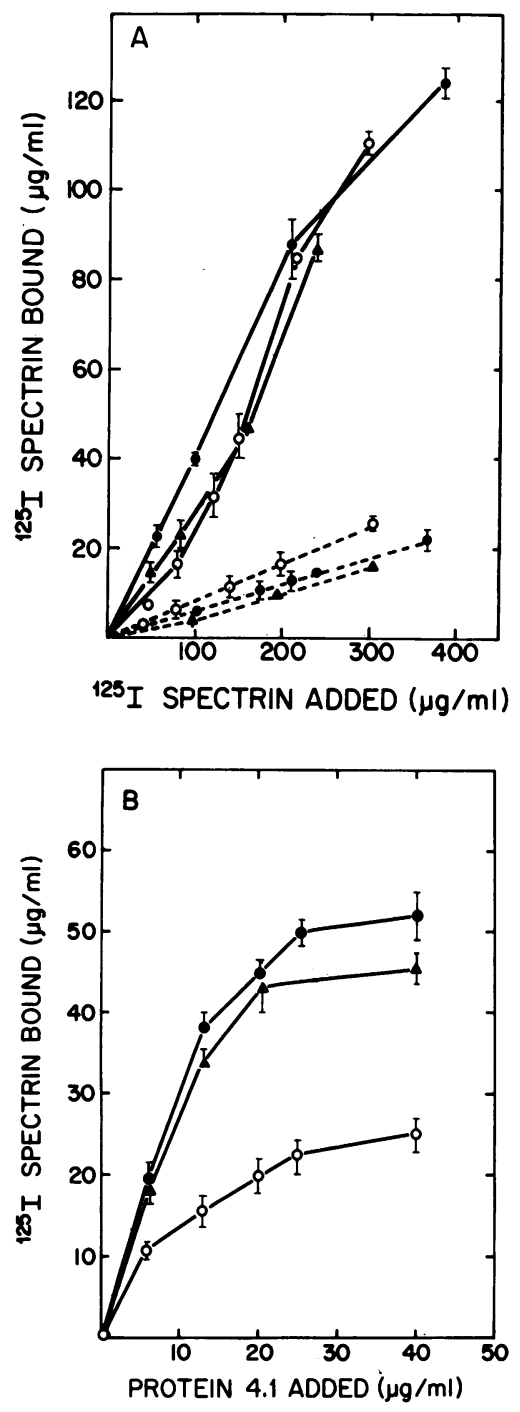

Figure 4. (A) Binding of normal (O), alpha- ( $\triangle$ ), and beta-thalassemic ( $\mathbf{a})$ spectrin dimer to actin in the presence (-) and absence (--) of normal protein 4.1 . The results of four experiments are presented. Increasing concentrations of normal and thalassemic spectrin dimer (0-30 $\mu \mathrm{g})$ were incubated with $24 \mu \mathrm{g}$ actin, with or without. normal protein $4.1(6 \mu \mathrm{g})$ as described in Methods. Error bars depict the SD. Note that both alpha- and beta-thalassemic spectrin dimer functioned normally in these interactions. (B) Binding of ${ }^{125}$ I-normal spectrin dimer to actin in the presence of normal (o), alpha-thalassemic $(\mathbf{\Delta})$, and beta-thalassemic ( $(\square)$ protein 4.1 in four experiments. Increasing concentrations of protein $4.1(0-3 \mu \mathrm{g})$ were incubated with fixed amounts of ${ }^{125} \mathrm{I}$-normal spectrin dimer $(12 \mu \mathrm{g})$ and $21 \mu \mathrm{g} \mathrm{F}$ actin for 1 $h$ at $24^{\circ} \mathrm{C}$ in buffer $\mathrm{D}$ (see Methods). Note there is a substantial decrease in the ability of

beta thalassemia protein 4.1 to enhance the binding of normal spectrin to $\mathrm{F}$ actin, whereas alpha-thalassemic protein 4.1 functions normally in this interaction.

analyses shows that the binding affinity of beta-thalassemic protein 4.1 for spectrin is diminished $\left(K_{\mathrm{d}}=1.2 \mu \mathrm{M}\right)$, compared with normal $\left(K_{\mathrm{d}}=0.26 \mu \mathrm{M}\right)$. Note that the binding capacity of the immobilized spectrin in these experiments is only a portion of the expected, assuming equimolar amounts of spectrin and protein 4.1. This may indicate that some of the spectrin dimers are not properly oriented to bind protein 4.1 when they are coupled to the $\mathrm{CNBr}$-Sepharose beads, or it may mean that some of the spectrin denatures during coupling.

The described alteration in beta-thalassemic protein 4.1 function is not caused by a quantitative deficiency, as measured by pyridine elution of the 4.1 band from SDS gels of thalassemic membranes (Table I). There is also no evidence suggesting increased aggregation of the thalassemic protein 4.1 in the membranes or in solution (data not shown), such as that recently described for protein 4.1 from sickle erythrocytes (32). The abnormal beta-thalassemic 4.1 presumably results from an acquired lesion or lesions that affect about half the 4.1 molecules. This assumption is supported by the abnormal elution profile of beta-thalassemic protein 4.1 from DEAE TSK-G50S anion exchange columns, which differs from that

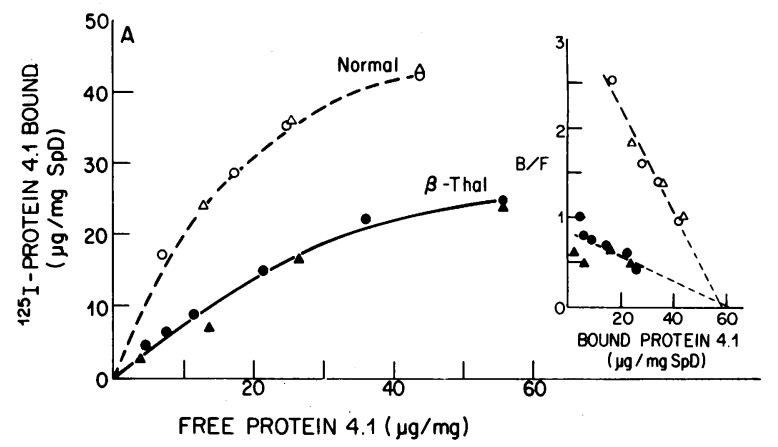

Figure 5. Interaction of purified protein 4.1 with spectrin. Binding of normal $(0, \Delta)$ and beta-thalassemic $(\circlearrowleft, \Delta)$ protein 4.1 to spectrinSepharose in two experiments. Various concentrations of ${ }^{125} \mathrm{I}$-protein $4.1(0-20 \mu \mathrm{g})$ and a fixed amount of spectrin $(40 \mu \mathrm{g})$ attached to Sepharose 4B were incubated in buffer $C$ for $90 \mathrm{~min}$ at $0^{\circ} \mathrm{C}$ (see Methods). The curves were corrected for nonspecific binding by subtracting the binding of protein 4.1 to BSA-Sepharose. Error bars depict the SD. There was a $45 \pm 2 \%$ reduction in the ability of beta-thalassemic protein 4.1 to bind to normal spectrin dimer in this system. Scatchard analysis (insert) shows that the binding affinity of beta-thalassemic protein 4.1 is diminished compared with normal ( $K_{d}$ [thal] $=1.2 \mu \mathrm{M}, K_{\mathrm{d}}[$ normal $\left.]=0.26 \mu \mathrm{M}\right)$.

of alpha-thalassemic and normal protein 4.1 ( 5 different experiments). Alpha-thalassemic and normal protein 4.1 elute at $142 \pm 10 \mathrm{mM} \mathrm{NaCl}$, whereas beta-thalassemic 4.1 elutes at $116 \pm 8 \mathrm{mM} \mathrm{NaCl}$. This observation indicates that both structural and functional alterations are present in protein 4.1 purified from beta-thalassemic red cells.

\section{Discussion}

Previous indirect evidence suggests that skeletal membrane proteins of thalassemic erythrocytes are abnormal in shape, composition, and function $(7,8)$. We, therefore, analyzed the different skeletal protein interactions in thalassemic red cells in search of specific defects. We found that such defects are relatively few in number and differ in alpha and beta thalassemia (Table III).

Spectrin, the major skeletal protein, incurred some slight damage in both alpha and beta thalassemia as shown by the presence of a trace amount of a fast mobility band on nondenaturing gels. Despite this limited structural alteration, thalassemic spectrin functions normally in spectrin self-association and in its interactions with other membrane skeletal proteins.

Table III. Skeletal Protein Functions

in Thalassemic Erythrocytes

\begin{tabular}{|c|c|c|}
\hline Interaction & $\begin{array}{c}\text { Alpha } \\
\text { thalassemia }\end{array}$ & $\begin{array}{c}\text { Beta } \\
\text { thalassemia }\end{array}$ \\
\hline Thalassemia spectrin self-association & Normal & Normal \\
\hline Thalassemia spectrin-normal IOVs & Normal & Normal \\
\hline Normal spectrin-thalassemia IOVs & $\begin{array}{l}\text { Abnormal } \\
(50 \pm 6 \%)\end{array}$ & Normal \\
\hline Thalassemia spectrin-actin-normal 4.1 & Normal & Normal \\
\hline Normal spectrin-actin-thalassemia 4.1 & Normal & $\begin{array}{l}\text { Abnormal } \\
(48 \pm 7 \%)\end{array}$ \\
\hline Normal spectrin-thalassemia 4.1 & Normal & $\begin{array}{l}\text { Abnormal } \\
(45 \pm 2 \%)\end{array}$ \\
\hline
\end{tabular}


A major defect is detected in the interaction of normal spectrin with its binding sites on membranes from alpha-, but not beta-, thalassemic red cells. The decreased ability of alphathalassemic IOVs to bind spectrin cannot be attributed to a quantitative deficiency of ankyrin, to unusual contamination of binding assays with outside-out membrane vesicles, or to significant proteolysis, as judged by quantitative analyses of electrophoresis gels and by sidedness assays. Alpha-thalassemic IOVs have increased hemoglobin attached to them, which reaches $\sim 5 \%$ of the total IOVs protein, or one to two molecules of hemoglobin for every molecule of ankyrin. Theoretically, this could account for the reduction in spectrin binding of alpha-thalassemic IOVs; however, beta-thalassemic IOVs, with a similar or even greater amount of attached hemoglobin, bind spectrin normally (Fig. $3 \mathrm{~B}$ ). The binding defect may, therefore, result from interference of the easily denatured, unpaired beta globin chains with the spectrin binding sites on the membrane by either steric hindrance or direct oxidative damage to the thalassemic ankyrin. The abnormal spectrin binding is similar to the defects described in other syndromes that involve the beta globin chain such as sickle cell disease (33) and severe unstable beta-hemoglobinopathies like Hb Nottingham or $\mathrm{Hb}$ Brockton (34). The excess beta chains in $\mathrm{HbH}$ disease are unstable and readily precipitate to form hemichromes (35), which bind to protein 3 with high affinity (36). $\mathrm{X}$ ray studies show that the cytoplasmic domain of protein 3 binds normal hemoglobin by inserting its NH-terminal end into the 2,3-diphosphoglycerate cavity between the beta globin chains (37). The alpha globin chains do not participate in this interaction. If hemichromes of beta globin tetramers $(\mathrm{HbH})$ bind in a similar fashion, this might explain why ankyrin, which binds nearby on protein 3 , is apparently damaged in alpha thalassemia but not beta thalassemia.

The defect in beta-thalassemic RBCs involves the skeletal protein interaction between the core skeletal components spectrin, actin, and protein 4.1. Beta-thalassemic protein 4.1 binds poorly to normal spectrin and only partially amplifies the binding of this spectrin to actin. Alpha-thalassemic protein 4.1 behaves normally in these interactions. As no quantitative deficiency of protein 4.1 is detected in beta-thalassemic membranes, we have to assume that an acquired lesion is present, which affects $\sim 50 \%$ of the beta-thalassemic protein 4.1 molecules. This assumption is supported to some extent by the abnormal elution profile of beta-thalassemic protein 4.1 from DEAE anion exchange columns. It might be caused by changes in the charge of beta-thalassemic protein 4.1, perhaps due to oxidation of its amino acid side chains.

Protein 4.1 interacts with a variety of different membrane components. It participates in spectrin-actin-4.1 interactions $(19,38-40)$, but it also binds to the red cell membrane via the glycophorins (41-43) and possibly protein $3(44)$, and phosphatidylserine (45-47). Recent data show that it has a crucial role in regulating red cell membrane stability (48). As previously mentioned, beta-thalassemic membranes show increased membrane fragility (7). Similar fragility is observed in patients with total or partial RBC protein 4.1 deficiency (48, $49)$ as well as in defects involving spectrin self-association ( 50 , $51)$, spectrin-actin-4.1 interactions $(47,49)$, and severe spectrin deficiency (6). Beta-thalassemic red cells are moderately spectrin deficient (23\% less spectrin than normal) and this deficiency may contribute to the observed membrane fragility (7); it is difficult to apportion the relative contributions of spectrin deficiency and the functional defect present in beta- thalassemic protein 4.1 . The possibility that spectrin deficiency in thalassemic membranes may be secondary to the defects in spectrin-IOV binding (alpha thal) or spectrin-4.1 interactions (beta thal) must also be considered.

That different molecular defects exist in the skeletal proteins of alpha- and beta-thalassemic red cells is of great interest and supports our hypothesis that unpaired alpha and beta globin chains may bind to and damage the membrane in different ways. Indeed, previous electron microscopic data suggest that this might be the case, as the morphological appearance of nucleated, as well as mature RBC is different in alpha (51) and beta thalassemia (52).

The loss of critical interactions between the core skeletal proteins (more evident in beta thalassemia), as well as interactions between the skeletal proteins and the overlying lipid bilayer (more evident in alpha thalassemia), might contribute to abnormal clustering of transmembrane proteins. This, in turn, could stimulate binding of autologous immunoglobulins (53, 54), and early recognition and removal of those erythrocytes from the circulation.

Further functional and structural studies are required for better understanding of the mechanism(s) responsible for such defects, and their role in the pathophysiology of the severe hemolysis in thalassemia.

\section{Acknowledgments}

The authors wish to thank Dr. Orah Platt for helpful discussions. We thankfully acknowledge the technical advice of Kathryn John and Jill Falcone.

This work was supported by a grant from the Cooley's Anemia Foundation, by National Institutes of Health grants 5P01-HL32262, 5P60-HL15157 and 5R01-AM34083 and by a grant from the American Physician Fellowship.

\section{References}

1. Weatherall, D. J., and J. B. Clegg. 1982. Thalassemia revisited. Cell. 29:7-9.

2. Rachmilewitz, E. A., E. Shinar, O. Shalev, U. Galili, and S. L. Schrier. 1985. Erythrocyte membrane alterations in beta thalassemia. Clin. Hematol. 14:163-182.

3. Rachmilewitz, E. A., B. M. Lubin, and S. B. Shohet. 1976. Lipid membrane peroxidation in beta-thalassemia. Blood. 47:495-505.

4. Kahane, I., A. Shifter, and E. A. Rachmilewitz. 1978. Crosslinking of red blood cell membrane proteins induced by oxidative stress in beta-thalassemia. FEBS (Fed. Eur. Biochem. Soc.) Lett. 85:267-270.

5. Kahane, I., and E. A. Rachmilewitz, 1976. Alterations in red blood cell membrane and the effect of vitamin $\mathrm{E}$ on osmotic fragility in beta-thalassemia major. Isr. J. Med. Sci. 12:11-15.

6. Mohandas, N., J. A. Chasis, and S. B. Shohet. 1983. The influence of the membrane skeleton on red cell deformability, membrane material properties, and shape. Sem. Hematol. 20:225-242.

7. Mohandas, N., E. A. Rachmilewitz, and S. Schrier. 1985. Red cell changes in alpha and beta thalassemia are different. Blood. 66(Suppl. 1):179a. (Abstr.)

8. Shinar, E., O. Shalev, E. A. Rachmilewitz, and S. L. Schrier. 1987. Erythrocyte membrane skeleton abnormalities in severe betathalassemia. Blood. 70:158-164.

9. Cividalli, G., H. Kerem, and E. A. Rachmilewitz. 1980. Globin synthesis in severe and intermediate homozygous beta-thalassemia in Israel. Ann. NY Acad. Sci. 344:132-140.

10. Fairbanks, G., T. L. Steck, and D. F. H. Wallach. 1971. Electrophoretic analysis of the major polypeptides of the human erythrocyte membrane. Biochemistry. 10:2606-2617.

11. Agre, P., E. P. Orringer, and V. Bennett. 1982. Deficient red cell spectrin in severe, recessively inherited spherocytosis. N. Engl. J. Med. 306:1155-1161. 
12. Fenner, C., R. R. Traut, D. T. Mason, and J. Wikman-Coffelt. 1975. Quantification of Coomassie blue stained proteins in polyacylamide gels based on analysis of eluted dye. Anal. Biochem. 63:603606.

13. Bennett, V., and D. Branton. 1977. Selective association of spectrin with the cytoplasmatic surface of human erythrocyte plasma membranes. Quantitative determination with purified [32P]-spectrin. J. Biol. Chem. 252:2753-2763.

14. Steck, T. L., and J. A. Kant. 1974. Preparation of impermeable ghosts and inside-out vesicles from human erythrocyte membranes. Methods Enzymol. 31:172-179.

15. Harris, H. W., and S. E. Lux. 1980. Structural characterization of the phosphorylation sites of human erythrocyte spectrin. J. Biol. Chem. 255:11512-11520.

16. Tyler, J. M., W. R. Hargreaves, and D. Branton. 1979. Purification of two spectrin binding proteins: biochemical and electron microscopic evidence for site-specific reassociation between spectrin and bands 2.1 and 4.1. Proc. Natl. Acad. Sci. USA. 76:5192-5196.

17. Cohen, C. M., and S. F. Foley. 1984. Biochemical characterization of complex formation by human erythrocyte spectrin, protein 4.1 and actin. Biochemistry. 23:6091-6098.

18. Spudich, J. A., and S. J. Watt. 1971. The regulation of rabbitskeletal muscle contraction. I. Biochemical studies of the interaction of the tropomyosin-troponin complex with actin and the proteolytic fragments of myosin. J. Biol. Chem. 246:4866-4871.

19. Ungewickell, E., P. M. Bennett, R. Calvert, V. Ohanian, and W. Gratzer. 1979. In vitro formation of a complex between cytoskeletal proteins of human erythrocytes. Nature (Lond.). 280:811-814.

20. Bolton, A. E., and W. M. Hunter. 1973. The labeling of proteins to high specific radioactivities by conjugation to a $\left[{ }^{125} \mathrm{I}\right]$-containing acylating agent. Application to the radio immunoassay. Biochem. J. 133:529-539.

21. Lowry, O. H., N. J. Rosebrough, A. L. Farr, and R. J. Randall. 1951. Protein measurement with the Folin phenol reagent. J. Biol. Chem. 193:265-275.

22. Morrow, J., and V. T. Marchesi. 1981. Self-assembly of spectrin oligomers in vitro: a basis for a dynamic cytoskeleton. J. Biol. Chem. 88:463-468.

23. Goodman, S. R., and S. A. Weidner. 1980. Binding of spectrin 2- 2 tetramers to human erythrocyte membranes. J. Biol. Chem. 255:8082-8086.

24. Wolfe, L. C., K. M. John, J. C. Falcone, A. M. Byrne, and S. E. Lux. 1982. A genetic defect in the binding of protein 4.1 to spectrin in a kindred with hereditary spherocytosis. N. Engl. J. Med. 307:13671374.

25. Becker, P. S., J. E. Spiegel, L. C. Wolfe, and S. E. Lux. 1983. High yield purification of protein 4.1 from human erythrocyte membranes. Anal. Biochem. 132:195-201.

26. Becker, P. S., C. M. Cohen, and S. E. Lux. 1986. The effect of mild diamide oxidation on the structure and function of human erythrocyte spectrin. J. Biol. Chem. 261:4620-4628.

27. Steck, T. L. 1972. Crosslinking the major proteins of the isolated erythrocyte membrane. J. Mol. Biol. 66:295-305.

28. Laemmli, U. K. 1970. Cleavage of structural proteins by bacteriophage T4. Nature (Lond.). 227:680-685.

29. Allen, D. W., S. Cadman, S. R. McCann, and B. Finkel. 1977. Increased membrane binding of erythrocyte catalase in hereditary spherocytosis and in metabolically stressed normal cells. Blood. 49:113-123.

30. Sauberman, N., N. L. Fortier, G. Fairbanks, G. J. R. O'Connor, and L. M. Snyder. 1979. Red cell membrane in hemolytic disease. Studies on variables affecting electrophoretic analysis. Biochim. Biophys. Acta. 556:292-313.

31. Snyder, L. M., L. Leb, J. Piotrowski, N. Sauberman, S. C. Liu, and N. L. Fortier. 1983. Irreversible spectrin-haemoglobin crosslinking in vivo: a marker for red cell senescence. Br. J. Haematol. 53:379-384.

32. Schwartz, R. S., A. C. Rybicki, R. H. Heath, and B. H. Lubin. 1987. Protein 4.1 in sickle erythrocytes. J. Biol. Chem. 262:1566615672.

33. Platt, O. S., J. Falcone, and S. E. Lux. 1985. Molecular defect in the sickle erythrocyte skeleton: abnormal spectrin binding to sickle inside-out vesicles. J. Clin. Invest. 75:226-271.

34. Platt, O. S., and J. F. Falcone. 1988. Membrane protein lesions in erythrocytes with Heinz bodies. J. Clin. Invest. 82:1051-1058.

35. Rachmilewitz, E. A., J. Peisach, T. B. Bradley, and W. E. Blumberg. 1969. Role of haemichromes in the formation of inclusion bodies in haemoglobin $\mathrm{H}$ disease. Nature (Lond.). 222:248-250.

36. Waugh, S. M., and P. S. Low. 1985. Hemichrome binding to band 3: nucleation of Heinz bodies on the erythrocyte membrane. Biochemistry. 24:34-39.

37. Walder, J. A., R. Chatterjee, T. L. Steck, P. S. Low, G. F. Musso, E. T. Kaiser, P. H. Rogers, and A. Arnone. 1984. The interaction of hemoglobin with the cytoplasmic domain of band 3 of the human erythrocyte membrane. J. Biol. Chem. 259:10238-10246.

38. Tyler, J. M., B. N. Reinhardt, and D. Branton. 1980. Association of erythrocyte membrane proteins. Binding of purified bands 2.1 and 4.1 to spectrin. J. Biol. Chem. 255:7034-7039.

39. Ohanian, V., L. C. Wolfe, K. M. John, J. C. Pinder, S. E. Lux, and W. B. Gratzer. 1984. Analysis of the ternary interaction of the red cell membrane skeletal proteins spectrin, actin and 4.1. Biochemistry. 23:4416-4420.

40. Correas, I., T. L. Leto, D. W. Speicher, and V. T. Marchesi. 1986. Identification of the functional site of erythrocyte protein 4.1 involved in spectrin-actin associations. J. Biol. Chem. 261:3310-3315.

41. Anderson, R. A., and R. E. Lovrein. 1984. Glycophorin is linked by band 4.1 protein to the human erythrocyte membrane skeleton. Nature (Lond.). 307:655-658.

42. Anderson, R. A., and V. T. Marchesi. 1985. Regulation of the association of membrane skeletal protein 4.1 with glycophorin by a polyphosphoinositide. Nature (Lond.). 318:295-298.

43. Mueller, T., and M. Morrison. 1981. Glycoconnectin (PAS 2), a membrane attachment site for the human erythrocyte cytoskeleton. In Erythrocyte Membranes 2: Recent Clinical and Experimental Advances. W. Kruckeberg, J. Eaton, and G. Brewer, editors. Alan R. Liss, Inc., New York. 95-112.

44. Pasternack, G. R., R. A. Anderson, T. C. Leto, and V. T. Marchesi. 1985. Interaction between protein 4.1 and band 3. J. Biol. Chem. 260:3676-3683.

45. Sato, S. B., and S. Ohnishi. 1983. Interaction of a peripheral protein of the erythrocyte membrane, band 4.1 with phosphatidylserine-containing liposomes and erythrocyte inside-out vesicles. Eur. J. Biochem. 130:19-25.

46. Cohen, A. M., S. C. Liu, L. H. Derick, and J. Palek. 1986. Ultrastructure studies of the interaction of spectrin with phosphatidylserine liposomes. Blood. 68:920-926.

47. Tchernia, G., N. Mohandas, and S. B. Shohet. 1981. Deficiency of skeletal membrane protein 4.1 in a homozygous hereditary elliptocytosis. Implications for erythrocyte membrane stability. J. Clin. Invest. 68:454-460.

48. Takatuwa, Y., G. Tchernia, M. Rossi, M. Benabadji, and N. Mohandas. 1986. Restoration of normal membrane stability to unstable protein 4.1-deficient erythrocyte membranes by incorporation of purified protein 4.1. J. Clin. Invest. 78:80-85.

49. Mohandas, N., M. R. Clark, B. P. Health, M. Rossi, L. C. Wolfe, S. E. Lux, and S. B. Shohet. 1982. A technique to detect reduced mechanical stability of red cell membranes: relevance to elliptocytic disorders. Blood. 59:768-776.

50. Palek, J. 1985. Hereditary elliptocytosis and related disorders. Clin. Hematol. 14:45-87.

51. Wickramasinghe, S. N., M. Hughes, S. R. Hollan, M. Horanyi, and J. Szelenyi. 1980. Electron microscopic and high resolution autoradiographic studies of the erythroblasts in haemoglobin $\mathrm{H}$ disease. $\mathrm{Br}$. J. Haematol. 45:401-404.

52. Polliack, A., and E. A. Rachmilewitz. 1973. Ultrastructural studies in beta-thalassemia major. Br. J. Haematol. 24:319-326.

53. Kay, M. M. B. 1978. Role of physiological autoantibody in the removal of senescent human red cells. J. Supramol. Struct. 9:555-567.

54. Galili, U., A. Korkesh, I. Kahane, and E. A. Rachmilewitz. 1983. Demonstration of a natural antigalactosyl IgG antibody on thalassemia red blood cells. Blood. 61:1258-1264. 